\title{
Seleksi, Karakterisasi, dan Identifikasi Bakteri Penghasil Kitinase yang Diisolasi dari Gunung Bromo Jawa Timur
}

\author{
Yati Sudaryati Soeka*) dan Sulistiani \\ Bidang Mikrobiologi, Puslit Biologi-LIPI, Jalan Raya Bogor Km 46, Cibinong 16911 \\ Diterima 28-05-2009 Disetujui 18-10-2010
}

\begin{abstract}
Selection, characterization and identification of bacteria that can produce chitinase enzyme were isolated from Bromo Mountain, East Java. The 48 isolates were tested for capability to degrade chitine qualitatively, semi quantitatively and quantitatively. The result showed that 2 isolates, B2-4 and NA S4-1 could degrade chitin, with activities of $4.8 .10^{-3}$ and $3.1 .10^{-3} \mathrm{U} / \mathrm{ml}$, after 1 and 2 days incubation respectively. By using molecular characterization methods, partial sequences of 16S rDNA and the primers 9F \& 1510R were identified as Stenotrophomonas sp.
\end{abstract}

Keywords: chitinase, Stenotrophomonas sp

\section{PENDAHULUAN}

Gunung Bromo merupakan Gunung berapi yang masuk dalam wilayah Taman Nasional Bromo Tengger Semeru. Taman nasional ini merupakan satu-satunya kawasan konservasi di Indonesia yang memiliki keunikan berupa laut pasir seluas 5,250 hektar, yang berada pada ketinggian $\pm 2,100$ meter dari permukaan laut. Terletak dalam kawasan Kabupaten Pasuruan, Kabupaten Probolinggo, Kabupaten Lumajang, dan Kabupaten Malang, Provinsi Jawa Timur (Dephut, 2007).

Keanekaragaman hayati di taman nasional ini diantaranya beberapa jenis tumbuhan antara lain: Jamuju (Dacrycarpus imbricatus), Cemara gunung (Casuarina sp.), Eidelweis (Anaphalis javanica), berbagai jenis anggrek dan jenis rumput langka (Styphelia pungieus). Terdapat sekitar 137 jenis burung, 22 jenis mamalia dan 4 jenis reptilia di taman nasional ini. Namun demikian informasi mengenai keanekaragaman hayati mikroba masih sangat kurang. Dalam penelitian ini telah dilakukan isolasi dan identifikasi bakteri air diwilayah Gunung Bromo dari beberapa tempat dengan ketinggian yang berbeda. Penelitian ini bertujuan untuk mengetahui kemampuan isolat bakteri tersebut dalam menghasilkan enzim kitinase. Isolat yang positif kemudian dikarakterisasi secara fenotipik dan molekuler, dengan analisis sekuen 16S rDNA (Don \& Brenner et al., 2003).
Kitinase adalah enzim yang mampu menghidrolisis kitin (polimer dari B-1,4 N-asetil-D-glukosamin) yang merupakan suatu polisakarida kedua terbanyak di alam setelah selulosa. Kitin sebagai polimer yang terdapat melimpah di tanah, memiliki struktur dan karakteristik yang unik.

Banyak hewan dan mikroorganisme menjadi penyumbang ketersediaan kitin di dalam tanah (Yurnaliza, 2008). Hasil hidrolisis kitin berupa senyawa kitooligosakarida bermanfaat dalam dunia kesehatan karena memiliki aktivitas anti tumor. Dalam bidang pertanian, kitinase dan mikroorganisme penghasilnya berperan sebagai agen pengendali hayati penyakit tanaman yang disebabkan oleh jamur. Kitinase menyebabkan terjadinya lisis pada dinding sel jamur yang umumnya mengandung kitin (Patil et al., 2000). Kitinase sangat menjanjikan untuk dimanfaatkan sebagai biopestisida yang aman dan ramah lingkungan karena kitinase dapat mendegradasi kitin yang merupakan komponen pada eksoskeleton serangga, nematoda dan dinding sel jamur (Terayama et al., 1993). Kitinase juga berperan sebagai agen biokonversi limbah kitin menjadi protein sel tunggal (Kobayashi et al., 1975) atau senyawa turunannya (Rattanakit et al., 2002). Dengan banyaknya fungsi dari kitinase, penelitian ini bertujuan untuk mendapatkan isolat unggul penghasil kitinase untuk dikoleksi LIPI-MC.

\footnotetext{
*Telp: +628129612170

Email: ceuceu_lipi@yahoo.com
} 


\section{BAHAN DAN METODE}

Pengambilan Sampel. Pengambilan sampel penelitian ini dilakukan di Gunung Bromo. Lokasi, waktu pengambilan sampel dan parameter lingkungan diuraikan dalam Tabel 1.

Isolasi dan Pengamatan Bakteri. Pembuatan media agar NA : Nutrient agar 100\% (NA): $23 \mathrm{~g} \mathrm{NA}$, akuades 1 liter dan Nutrien agar 20\% (1/10 NA): 2,3 g $\mathrm{NA}$, agar 12,7g, akuades 1 liter disterilkan menggunakan autoklaf. Isolasi dilakukan dengan metoda cawan sebar. Sample (air embun dan air tanah) diencerkan dengan akuades steril di mikrotube, divortek supaya homogen kemudian ditumbuhkan dengan cara sebar permukaan di 2 macam media, media Nutrient Agar 100\% (NA) dan media nutrient agar 20\% (1/10 NA). Diinkubasi selama 3 hari dan dilakukan penghitungan jumlah bakteri. Bakteri yang mempunyai morfologi berbeda diambil dan dilakukan pemurnian lebih lanjut (Pelczar \& Chan, 2005).

Preparasi Koloidal Kitin. Ditimbang sebanyak $20 \mathrm{~g}$ kitin dari kulit udang ditambah $400 \mathrm{ml} \mathrm{HCl}$ pekat, distirer selama 2 jam kemudian diinkubasi di dalam lemari pendingin selama 24 jam. Larutan tersebut disaring dengan glass wool, filtratnya ditambah akuades steril dingin dan dinetralkan dengan $10 \mathrm{~N} \mathrm{NaOH}$ sampai $\mathrm{pH} 7,0$. Larutan disentrifugasi dengan kecepatan $7,780 \mathrm{~g}$ selama 10 menit dan endapannya diambil. Endapan dibilas dengan akuades steril dan disentrifugasi lagi dengan kecepatan 7,780 g selama 10 menit. Endapan yang berupa koloidal kitin disimpan di dalam lemari pendingin (Widhyastuti, 2007).

Media Seleksi. Media kitin agar (koloidal kitin 1\%, pepton $0,1 \%, \mathrm{KH}_{2} \mathrm{PO}_{4} 0,1 \%$, $\mathrm{MgSO}_{4} .7 \mathrm{H} 2 \mathrm{O} 0,05 \%$, agar $2 \%$ ) digunakan untuk menyeleksi bakteri murni yang dapat merombak kitin dituangkan dalam cawan petri. Inkubasi dilakukan pada suhu kamar selama 3 hari. Hasil pengujian secara kualitatif menunjukkan bahwa isolat yang memiliki aktivitas kitinase ditandai dengan adanya zona bening disekitar koloni.
Media kultur bakteri. Isolat yang menghasilkan aktivitas kitinase tertinggi dengan waktu inkubasi tertentu yang dipakai untuk perlakuan selanjutnya. Dalam perlakuan selanjutnya menginokulasikan mikroba dalam media kultur bakteri Luria Bertani (pepton 1\%, ekstrak ragi 0,5\%, dan $\mathrm{NaCl} 0,1 \%$ ) pada $\mathrm{pH}$ 7,2 diinkubasi selama 1 hari pada suhu kamar di atas pengocok double shaker NR-150 dengan kecepatan 120 rpm (Mahata et al., 2008). Sebanyak $0,5 \mathrm{ml}$ dipipet masing-masing dimasukkan ke dalam $25 \mathrm{ml}$ media cair kitin $1 \%$ dengan variasi $\mathrm{pH}$ bufer $(\mathrm{pH}$ 3-9). Larutan bufer yang digunakan adalah $0,05 \mathrm{M}$ bufer

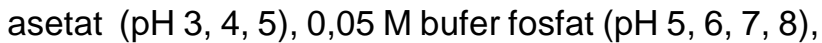
$\mathrm{pH} 7$ dalam aquades dan $0,05 \mathrm{M}$ bufer tris- $\mathrm{HCl}$ (pH 8, 9).

Produksi Kitinase. Produksi inokulum dilakukan dengan cara bakteri ditumbuhkan pada media agar miring NA, diinkubasi pada suhu kamar sampai berumur 3 hari. Selanjutnya ditambahkan akuades steril. Suspensi mikroba bakteri diukur kerapatan optiknya (OD) dengan spektrofotometer pada ë $600 \mathrm{~nm}$ sampai OD mencapai 0,5. Produksi kitinase dilakukan dengan menginokulasikan inokulum ke dalam $25 \mathrm{ml}$ media produksi (koloidal kitin $1 \%$, pepton $0,1 \%, \mathrm{KH}_{2} \mathrm{PO}_{4} 0,1 \%$, $\mathrm{MgSO}_{4} \cdot 7 \mathrm{H}_{2} \mathrm{O} 0,05 \%$ ) dengan $\mathrm{pH} 7$ dan diinkubasi pada suhu kamar selama 1-7 hari di atas pengocok dengan kecepatan $120 \mathrm{rpm}$. Setiap hari dilakukan pengambilan sampel sebanyak $2 \mathrm{ml}$ dan dipisahkan filtrat dan endapannya, disentrifugasi dengan kecepatan $10.160 \mathrm{~g}$ selama 5 menit. Filtrat digunakan sebagai larutan enzim dan diuji aktivitas kitinasenya.

Pengujian Aktivitas Kitinase. Aktivitas kitinase diuji dengan mengukur kadar gula amino sebagai produk hidrolisis kitin oleh kitinase. Konsentrasi gula amino diukur menggunakan Metode Reissig (1955). Senyawa $\mathrm{N}$-asetil glukosamin (GlcNAc) digunakan sebagai standar untuk penghitungan aktivitas kitinase. Satu unit kitinase adalah banyaknya enzim yang dapat menghasilkan $1 \mu \mathrm{mol} N$-asetil glukosamin dari substrat

Tabel 1. Lokasi, waktu pengambilan sampel dan parameter lingkungan

\begin{tabular}{|c|c|c|c|c|c|c|}
\hline $\begin{array}{l}\text { Sumber } \\
\text { sampel }\end{array}$ & $\begin{array}{l}\text { Ketinggian } \\
(\mathrm{m})\end{array}$ & $\begin{array}{l}\text { Tekanan } \\
\text { (mbar) }\end{array}$ & $\begin{array}{l}\text { Temperatur } \\
\left({ }^{\circ} \mathrm{C}\right)\end{array}$ & Koordinat & Nama lokasi & Keterangan detail sampel \\
\hline Air embun & 2786 & 732 & 11 & $\begin{array}{l}07^{\circ} 54.239 \mathrm{~S} \\
112^{\circ} 57.081 \mathrm{E}\end{array}$ & $\begin{array}{l}\text { Ds. Penanjakan, Kec. Tosari Kab. } \\
\text { Pasuruan }\end{array}$ & $\begin{array}{l}\text { Embun yang menggantung } \\
\text { diujung daun cemara }\end{array}$ \\
\hline Air tanah & 2757 & 739 & 13 & $\begin{array}{l}07^{\circ} 54.187 \mathrm{~S} \\
112^{\circ} 57.018 \mathrm{E}\end{array}$ & $\begin{array}{l}\text { Ds. Penanjakan, Kec. Tosari Kab. } \\
\text { Pasuruan }\end{array}$ & Sumber air pegunungan \\
\hline Air tanah & 2241 & 781 & 22 & $\begin{array}{l}07^{\circ} 55.333 \mathrm{~S} \\
112^{\circ} 57.829 \mathrm{E}\end{array}$ & $\begin{array}{l}\text { Dsn. Cemoro Lawang, Ds. } \\
\text { Ngadisari, Kec Sukapura Kab. } \\
\text { Probolinggo }\end{array}$ & $\begin{array}{l}\text { Air kran Hotel Cemara Indah } \\
\text { yang berasal dari sumber air } \\
\text { tanah }\end{array}$ \\
\hline Air tanah & 1215 & 879 & 26 & $\begin{array}{l}07^{\circ} 54.740 \mathrm{~S} \\
113^{\circ} 02.189 \mathrm{E}\end{array}$ & $\begin{array}{l}\text { Ds Sapi kerep, Kec. Sukapura, } \\
\text { Kab. Probolinggo }\end{array}$ & $\begin{array}{l}\text { Air kran rumah penduduk yang } \\
\text { berasal dari sumber air tanah }\end{array}$ \\
\hline
\end{tabular}


koloidal kitin per menit pada suhu $50^{\circ} \mathrm{C}, \mathrm{pH} 7,0$. Larutan kitinase yang menghasilkan GlcNAc terlalu tinggi diencerkan terlebih dahulu dan faktor pengenceran digunakan dalam perhitungan aktivitasnya. Sebanyak $0,5 \mathrm{ml}$ larutan enzim direaksikan dengan $0,5 \mathrm{ml}$ substrat koloidal kitin $1 \%$ dengan $\mathrm{pH} 7$ dan diinkubasi pada suhu $50^{\circ} \mathrm{C}$ selama 30 menit. Reaksi enzimatis dihentikan dengan memasukkan campuran ke dalam air mendidih selama 5 menit. Selanjutnya disentrifugasi dengan kecepatan 10,160 g selama 5 menit dan filtrat dipisahkan dari endapan. Sebanyak $250 \mu$ filtrat ditambah $50 \mu \mathrm{l}$ potasium tetraborat, dididihkan selama 3 menit dan didinginkan dengan segera. Ditambahkan $1,25 \mathrm{ml}$ reagen 4-(dimetilamino)benzaldehida (DMAB), diinkubasi pada suhu $37^{\circ} \mathrm{C}$ selama 20 menit dan OD dibaca dengan spektrofotometer pada ë $584 \mathrm{~nm}$.

Media produksi dengan variasi $\mathrm{pH}$ substrat koloidal kitin $1 \%$. Produksi kitinase dilakukan dengan menginokulasikan isolat dengan nilai kerapatan optik tertinggi ke dalam $10 \mathrm{ml}$ media produksi (koloidal kitin $1 \%$, pepton $0,1 \%, \mathrm{KH} 2 \mathrm{PO} 40,1 \%, \mathrm{MgSO}_{4} \cdot 7 \mathrm{H}_{2} \mathrm{O} 0,05 \%$ ) dengan $\mathrm{pH} 7$ dalam aquades dan diinkubasi pada suhu kamar selama 1 hari di atas pengocok dengan kecepatan $120 \mathrm{rpm}$. Sampel sebanyak $2 \mathrm{ml}$ setelah diinkubasi 1 hari lalu dipisahkan filtrat dan endapannya, disentrifugasi dengan kecepatan $10.160 \mathrm{~g}$ selama 5 menit. Filtrat digunakan sebagai larutan enzim dan diuji aktivitas kitinasenya dengan variasi $\mathrm{pH}$ substrat. Sebanyak 0,5 ml larutan enzim direaksikan dengan 0,5 $\mathrm{ml}$ substrat koloidal kitin $1 \%$ dengan variasi $\mathrm{pH}$ substrat bufer ( $\mathrm{pH} 3-9)$. Larutan bufer yang digunakan adalah $0,05 \mathrm{M}$ bufer asetat ( $\mathrm{pH} 3,4,5), 0,05 \mathrm{M}$ bufer fosfat $(\mathrm{pH} 5,6,7,8)$, dan $0,05 \mathrm{M}$ bufer tris- $\mathrm{HCl}$ $(\mathrm{pH} \mathrm{8,} \mathrm{9).}$

Karakterisasi dan identifikasi isolat penghasil enzim kitinase. Isolat penghasil kitinase dikarakterisasi secara fenotipik dan molekuler. Karakterisasi fenotipik meliputi pengamatan morfologi sel dan koloni, karakter fisiologis karakter fenotipik dilakukan dengan metode profile matching yang mengacu pada Bergey's Manual of Systematic Bacteriology (Don \& Brenner et al., 2003). Karakteristik molekular dilakukan berdasarkan sekuen 16S rDNA dengan primer 9F (5'-GAGTTTGATCCTGGCTCAG-3') dan 1510R (5'-GGCTACCTTGTTACGACTT-3').

Amplifikasi 16S rDNA. DNA isolat bakteri diisolasi menggunakan Wizard Genomic DNA Purification Kit (Promega). Amplifikasi 16S rDNA menggunakan metode
PCR dengan primer universal yaitu 9F dan 1510R. Reaksi PCR menggunakan Thermalcycler (Takara, Shuzo, Co. Ltd.) sebagai berikut : denaturasi $95^{\circ} \mathrm{C}$ selama 3 menit, dilanjutkan 30 siklus yang terdiri dari denaturasi $95^{\circ} \mathrm{C}$ selama 30 detik, perekatan $50^{\circ} \mathrm{C}$ selama 30 detik, pemanjangan $72^{\circ} \mathrm{C}$ selama 90 detik. Pemanjangan akhir $72^{\circ} \mathrm{C}$ selama 7 menit. Hasil produk PCR dipurifikasi, dilanjutkan dengan cyclesekuensing dengan template $9 \mathrm{~F}$ dan $1510 \mathrm{R}$. Hasil cyclesekuensing dipurifikasi dan dilanjutkan dengan sekuensing di Genetic analyzerABI 3130. Hasil sekuensing dicek dan diedit/trimming menggunakan program Bioedit. Fasta yang diperoleh disambungkan menggunakan program Clustal X. Hasil penyambungan (aligment) di Blast di gen Bank NCBI.

\section{HASIL DAN PEMBAHASAN}

Dari sampel air embun dan air tanah yang diisolasi, didapat sebanyak 47 isolat bakteri murni. Hanya dua isolat yang positif dapat merombak kitin yaitu sampel air tanah dari Kabupaten Pasuruan B2-4 dan air tanah NA S4-1 dari Kabupaten Probolinggo (Tabel 2). Setiap isolat murni dipelihara dalam media miring Nutrient Agar.

Hasil pengujian secara kualitatif menunjukkan bahwa sebanyak 2 isolat memiliki aktivitas kitinase, yang ditandai dengan adanya zona bening disekitar koloni (Gambar 1). Mikroba yang dapat mensekresikan enzim-enzim kitinolitik ekstraseluler akan membentuk areal bening pada media padat yang mengandung kitin (Priest, 1984). Menurut Faath (1994) perbedaan laju degradasi kitin dapat ditunjukkan dengan penampakkan areal bening di sekeliling koloni pada agar yang mengandung kitin. Selanjutnya isolat-isolat yang menunjukkan positif aktivitas kitinase secara kualiatatif diukur secara semi-kuantitatif dengan cara membandingkan diameter zona bening disekitar koloni dengan diameter koloni.

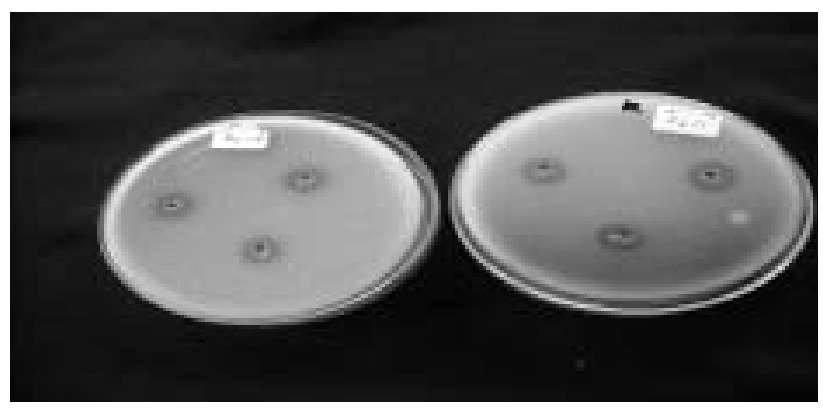

Gambar 1. Zona bening dari bakteri B2-4 (kiri) dan NA S4-1 (kanan) perombak kitin 
Tabel 2. Jenis-jenis bakteri yang disolasi dari Gunung Bromo Jawa Timur dan kemampuan kitinasenya

\begin{tabular}{|c|c|c|c|}
\hline No. & Nama sampel & Isolat & Uji Kitinase \\
\hline$\overline{1}$ & 1. Air embun. Ds. & NA S $1 / 1$ & - \\
\hline 2 & Penanjakan, Kec. Tosari & NA S $1 / 2$ & - \\
\hline 3 & Kab. Pasuruan. 2786 m & NA S $1 / 4$ & - \\
\hline 4 & dpl. & 1/10NA S1/1 & - \\
\hline 5 & & $1 / 10 N A$ S $1 / 2$ & - \\
\hline 6 & & $1 / 10 N A$ S $1 / 3$ & - \\
\hline 7 & 2. Air tanah. Ds. & NA S2/1 & - \\
\hline 8 & Penanjakan, Kec. Tosari & NA S $2 / 2$ & - \\
\hline 9 & Kab. Pasuruan. 2757 & NA S $2 / 3$ & - \\
\hline 10 & & NA S2/4 & - \\
\hline 11 & & NA S $2 / 5$ & - \\
\hline 12 & & NA S2/6 & - \\
\hline 13 & & NA S2/7 & - \\
\hline 14 & & NA S2/8 & - \\
\hline 15 & & NA S $2 / 10$ & - \\
\hline 16 & & B2-4 & +++ \\
\hline 17 & & B2-6 & - \\
\hline 18 & & B2-7 & - \\
\hline 19 & & $1 / 10 N A$ S2/4 & - \\
\hline 20 & & $1 / 10 N A$ S2/5 & - \\
\hline 21 & & 1/10NA S2/6 & - \\
\hline 22 & & $1 / 10 N A$ S2/9 & - \\
\hline 23 & & 1/10NA S2/11 & - \\
\hline 24 & 3. Air tanah. Dsn. Cemoro & NA S3/1 & - \\
\hline 25 & Lawang, Ds. Ngadisari, & NA S3/2 & - \\
\hline 26 & Kec Sukapura Kab. & NA S3/4 & - \\
\hline 27 & Probolinggo. 2241 m dpl. & NA S3/5 & - \\
\hline 28 & & NA S3/6 & - \\
\hline 29 & & NA S3/7 & - \\
\hline 30 & & NA S3/8 & - \\
\hline 31 & & NA S3/9 & - \\
\hline 32 & & NA S3/10 & - \\
\hline 33 & & B3-1 & - \\
\hline 34 & & B3-5 & - \\
\hline 35 & & B3-7 & - \\
\hline 36 & & 1/10NA S3/1 & - \\
\hline 37 & & 1/10NA S3/2 & - \\
\hline 38 & & 1/10NA S3/3 & - \\
\hline 39 & & 1/10NA S3/4 & - \\
\hline 40 & & $1 / 10 N A$ S3/5 & - \\
\hline 41 & 4. Air tanah. Ds. Sapi & NA S4-1 & +++ \\
\hline 42 & kerep, Kec. Sukapura, & NA S4-2 & - \\
\hline 43 & Kab. Probolinggo. $1215 \mathrm{~m}$ & 1/10 NA S4/1 & - \\
\hline 44 & dpl. & 1/10 NA S4/2 & - \\
\hline 45 & & 1/10 NA S4/3 & - \\
\hline 46 & & $1 / 10$ NA S4/4 & - \\
\hline 47 & & 1/10 NA S4/5 & - \\
\hline
\end{tabular}

Hasil penghitungan secara semi-kuantitatif menunjukkan terdapat dua isolat memiliki diameter zona bening dengan nilai lebih besar dan sama dengan 2. Hasil bagi antara diameter zona bening dan diameter koloni dinyatakan sebagai aktivitas enzim secara nisbi, sedangkan isolat negatif yaitu isolat yang tidak dapat merombak kitin ada 45 isolat.

Kemampuan dari masing-masing isolat bervariasi sesuai dengan isolatnya. Selanjutnya isolat dengan aktivitas nisbi sama dan lebih besar dengan 2 diuji kemampuan kitinasenya secara kuantitatif. Konsentrasi koloidal kitin yang digunakan untuk penapisan isolat dengan memperlihatkan zona bening yang jelas di sekitar koloni biasanya mengandung sekitar koloidal kitin 1\%. Menurut Hsu, (1975) zona bening paling jelas terlihat pada media agar kitin yang mengandung koloidal kitin $0,4 \%$, pada konsentrasi koloidal kitin yang lebih rendah $(0,1-0,2 \%)$ tidak ada penampakan zona bening dan pada konsentrasi yang lebih tinggi atau 1-2\% zona bening yang dihasilkan terlihat agak kabur. Monreal, (1968) menggunakan agar kitin dengan "double layer" untuk penapisan bakteri penghasil kitinase, dan pada lapisan bawah digunakan media mengandung ekstrak ragi $0,5 \%$ dan agar $2 \%$, dan yang bagian atas media mengandung koloidal kitin $1 \%$. Secara keseluruhan seleksi secara kualitatif isolat penghasil kitinase yang dilakukan dalam penelitian ini menunjukkan hasil yang baik dan jelas.

Isolat yang dapat mendegradasi kitin ditumbuhkan pada media kultur bakteri Luria Bertani (pepton 1\%, ekstrak ragi $0,5 \%$, dan $\mathrm{NaCl} 0,1 \%$ ) pada $\mathrm{pH}$ 7,2 diinkubasi selama 1 hari pada suhu kamar di atas pengocok dengan kecepatan $120 \mathrm{rpm}$ (Mahata et al., 2008). Pada bakteri B2-4 lebih cepat dan lebih tinggi kerapatan optiknya diukur pada spektrofotometer dengan ë $584 \mathrm{~nm}$ dibandingkan dengan NA S4-1 (Gambar 2 dan Gambar 3). Pada Gambar 2 dapat dilihat kerapatan optik tertinggi B2-4 didapat dari perlakuan media awal pH 7 dalam aquades dengan waktu inkubasi 1 hari yaitu sebesar 0,358 . Sedangkan isolat NA S4-1 kerapatan optik tertinggi didapat dari perlakuan media awal $\mathrm{pH} 7$ dalam aquades dengan waktu inkubasi 2 hari yaitu sebesar 0,286 , lebih kecil dari isolat B2-4. Derajat keasaman $(\mathrm{pH})$ media berpengaruh terhadap pertumbuhan dan produksi enzim dan enzim memiliki $\mathrm{pH}$ optimum yang khas, yaitu $\mathrm{pH}$ yang menyebabkan aktivitas maksimal. Tetapi $\mathrm{pH}$ optimum enzim tidak perlu sama dengan $\mathrm{pH}$ lingkungan normalnya, dengan $\mathrm{pH}$ yang mungkin sedikit berada di atas atau di bawah pH optimum (Lehninger, 1988). Menurut Fresht, 1985 bahwa setiap enzim memiliki kisaran $\mathrm{pH}$ optimum yaitu kisaran $\mathrm{pH}$ dimana enzim menunjukkan aktivitas maksimum dengan stabilitas yang tinggi.

Kondisi media awal $\mathrm{pH} 7$ dalam aquades yang dipakai pada penelitian selanjutnya dengan perlakuan berbagai variasi waktu inkubasi dari 1-7 hari (Gambar 3). Metode Reissig (1955) digunakan untuk mendeteksi gula asetilamino. Reaksi antara gula amino dengan potasium tetraborat dalam konsidi alkali dan pemanasan menghasilkan senyawa intermediat asetil heksosamine. Dapat dilihat aktivitas tertinggi didapat 


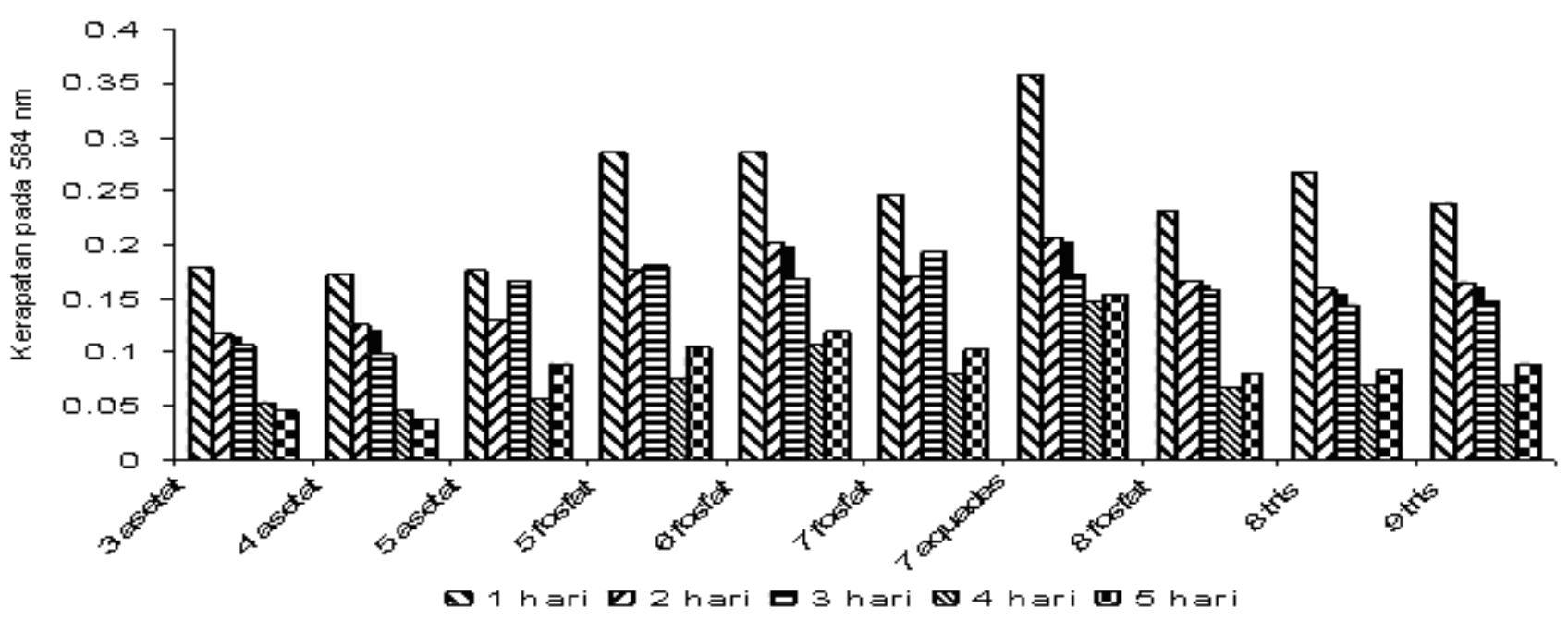

Media awal $\mathrm{B}$ 2-4 dengan variasi $\mathrm{pH}$ buter dan $\mathrm{pH} 7$ dalam aquades

Gambar 2. Kerapatan optik B2-4 pada media awal dengan variasi $\mathrm{pH}$ dalam bufer dan $\mathrm{pH}$ dalam aquades

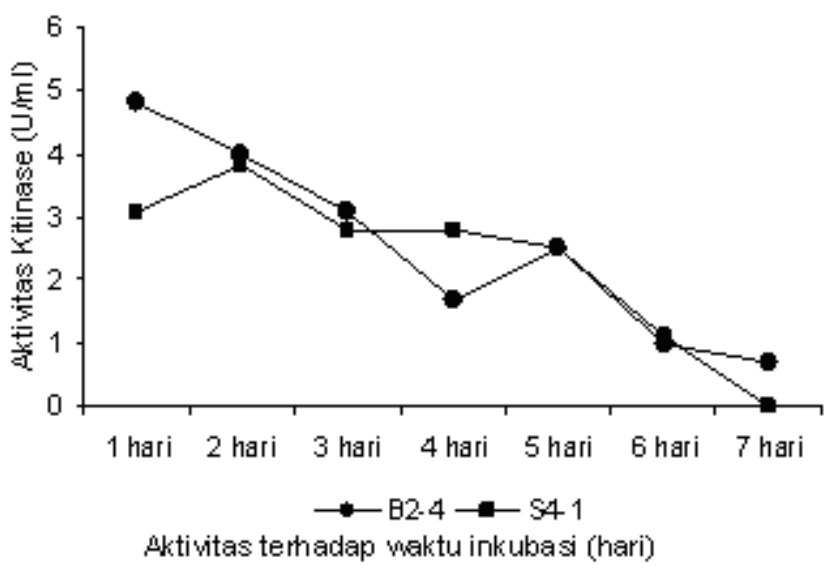

Gambar 3. Aktivitas kitinase B2-4 dan NA S4-1 terhadap waktu inkubasi

dari isolat bakteri B2-4 dengan waktu inkubasi 1 hari sebesar 4,8 $\times 10^{-3} \mathrm{U} / \mathrm{ml}$ dan NA S4-1 dengan waktu inkubasi 2 hari sebesar $3,1 \times 10^{-3} \mathrm{U} / \mathrm{ml}$. Hasil ini masih lebih kecil kalau dibandingkan dengan aktivitas hasil dari bakteri isolat 99 dan Enterobacter sp. G-1 (Mahata et al., 2008) dan dari Aspergillus rugulosus 501 (Widhyastuti, 2007). Kalau melihat dari hasil foto dan penghitungan secara semikuantitatif aktinomisetes BB 3.2 (Soeka, 2009) hampir sama, tetapi aktivitas kitinase B2-4 dan NA S4-1 hasilnya sangat kecil. Ada kemungkinan media kultur bakteri Luria Bertani (Mahata et al., 2008) kurang/tidak cocok, untuk penelitian selanjutnya harus dicoba dengan media lain. Dapat dilihat setelah hari pertama untuk B2-4 dan setelah hari kedua untuk NA S4-1 aktivitas kitinasenya terus menurun hal ini dimungkinkan terjadinya kenaikan aktivitas enzim dengan inkubasi dalam waktu jam tidak hari lagi. Jika keadaan baik, hampir semua bakteri mampu berkembang biak dengan amat cepat. Lamanya dapat satu jam hingga beberapa hari. Lama waktu ini tergantung pada macam bakteri, umur biakan, dan nutrien yang terdapat dalam media yang disediakan Mikroorganisme mempunyai masa pertumbuhan yang bervariasi dimana dalam aktivitas metabolisme tersebut mikroorganisme memiliki beberapa fase dalam pertumbuhannya. Pada awal pertumbuhan fase yang dilalui adalah fase pertumbuhan kemudian aktivitas metabolisme akan menurun setelah mikroorganisme melewati fase puncak pertumbuhannya. Fase-fase pertumbuhan tersebut sangat berpengaruh terhadap enzim yang dihasilkan oleh mikroorganisme untuk membantu pencernaan makanannya (Volk \& Wheeler, 1988).

Laju reaksi bergantung pada kondisi larutan dan konsentrasi substrat. Kondisi-kondisi yang menyebabkan denaturasi protein seperti temperatur tinggi, konsentrasi garam yang tinggi, dan nilai $\mathrm{pH}$ yang terlalu tinggi atau terlalu rendah akan menghilangkan aktivitas enzim. Sedangkan peningkatan konsentrasi substrat cenderung meningkatkan aktivitasnya. Untuk menentukan kelajuan maksimum suatu reaksi enzimatik, konsentrasi substrat ditingkatkan sampai laju pembentukan produk yang terpantau menjadi konstan. Konsentrasi ion hidrogen (yaitu keasaman atau kebasaan) larutan sangat mempengaruhi aktivitas suatu enzim. Hal ini disebabkan karena asam amino yang merupakan pusat aktif enzim harus berada dalam keadaan ionisasi yang tepat agar menjadi aktif. Kebanyakan enzim menunjukkan aktivitas maksimum pada kisaran netral, $\mathrm{pH} 6$ sampai 8 . Pengaruh $\mathrm{pH}$ terhadap suatu enzim bervariasi tergantung jenisnya. 
Ada enzim yang bekerja secara optimal pada kondisi asam. Ada juga yang bekerja secara optimal pada kondisi basa.Untuk setiap enzim kita dapat memastikan $\mathrm{pH}$ minimum, maksimum, dan optimum (Volk \& Wheeler, 1988). Hasil penelitian ini sesuai dengan hasil penelitian sebelumnya yang dilakukan oleh Yurnaliza et al., (2008) mengatakan beberapa penelitian enzim menunjukkan bahwa $\mathrm{pH}$ berada pada kisaran netral dapat meningkatkan pertumbuhan mikroba dan kemampuannya mensintesis kitinase. Menurut Webb dan Dixon (1979), peningkatan aktivitas enzim pada $\mathrm{pH}$ optimum dapat dihubungkan dengan adanya perubahan ionisasi dalam gugus ionik enzim pada sisi aktif sehingga konformasi sisi aktif menjadi lebih efektif dalam mengikat dan mengubah substrat menjadi produk.

Selanjutnya isolat B2-4 dianalisa aktivitas kitinasenya dengan variasi $\mathrm{pH}(3-9)$ substrat kitin $1 \%$, dapat dilihat dalam Gambar 3, didapat aktivitas tertinggi pada $\mathrm{pH} 8$ fosfat sebesar $17,54 \times 10^{-2} \mathrm{U} / \mathrm{ml}$. Hasil ini masih lebih besar dari hasil penelitiannya Nasran, et al., (2003) aktivitas kitinase dari Vibrio harveyi pada pH 8 dengan masa inkubasi 5 hari mencapai $6,0 \times 10^{-5} \mathrm{U} / \mathrm{ml}$. Dan sesuai dengan penelitian dari Rochima (2006) Bacillus papandayan asal Kawah Kamojang mempunyai pH optimum pada $\mathrm{pH}$ 8. Dengan pH 8 berarti bersifat alkali. Kebanyakan bakteri hidup paling baik pada keadaan sekitar netral $(\mathrm{pH} 7)$ karena itu sebelum digunakan, kebanyakan medium disesuaikan pada pH sekitar 7. Hanya sedikit bakteri hidup dalam lingkungan ekstrim kisaran $\mathrm{pH}$ (misalnya 8-9), oleh karena itu $\mathrm{pH}$ harus disesuaikan dengan jenis yang ditumbuhkan. Konsentrasi ion hidrogen (yaitu keasaman atau kebasaan) larutan sangat mempengaruhi aktivitas suatu enzim. Hal ini disebabkan karena asam amino yang merupakan pusat aktif enzim harus berada dalam keadaan ionisasi yang tepat agar menjadi aktif. Kebanyakan enzim menunjukkan aktivitas maksimum pada kisaran netral, pH 6 sampai 8 (Volk \& Wheeler, 1988).

Berdasarkan hasil identifikasi isolat tingkat spesies dengan metode molekuler 16S rDNA diketahui bahwa isolat B2-4 dan NA S4-1 adalah Stenotrophomonas sp. (Tabel 3). Stenotrophomonas adalah spesies termasuk genus Stenotrophomonas, keluarga Xanthomonadaceae, Order Xanthomonadales, kelas Gammaproteobacteria dan phylum Proteobacteria. Hasil ini didukung analisis karakter morfologi dan fisiologi dan ternyata sesuai dengan yang disebutkan dalam Bergey's Manual of Systematic Bacteriology Second ed. Springer.

\section{KESIMPULAN}

Berdasarkan hasil penelitian dapat disimpulkan bahwa dari 48 isolat yang mempunyai kapasitas dapat merombak kitin menjadi kitinase adalah 2 isolat B2-4 dan NA S4-1. Isolat B2-4 mempunyai aktivitas kitinase

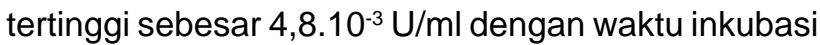
1 hari dan NA S4-1 mempunyai aktivitas kitinase tertinggi sebesar $3,1 \times 10^{-3} \mathrm{U} / \mathrm{ml}$ dengan waktu inkubasi

Tabel 3. Kecocokan profil analisa karakter morfologi dan fisiologi isolat B2-4 dan NA S4-1 penghasil kitinase dengan genus acuan berdasarkan Bergey's Manual of Systematic Bacteriology (Don J. Brenner et al. 2003) Species stenotrophomonas dalam bergey's

\begin{tabular}{lccc}
\multicolumn{1}{c}{ Unit Karakter } & manual of systematic bacteriology & NA B2-4 & NA S4-1 \\
\hline Gram & negatif & negatif & negatif \\
Motilitas & tidak motil & tidak motil & tidak motil \\
Bentuk sel & batang & batang & batang \\
Ukuran sel $(\mu \mathrm{m})$ & 1 & 1 & 1 \\
Bentuk koloni & bulat & bulat & bulat \\
Ukuran koloni $(\mathrm{mm})$ & $1-1,5$ & $1-1,5$ & $1-1,25$ \\
Tepi sel & rata & rata & rata \\
Elevasi & agak cembung & agak cembung & agak cembung \\
Permukaan & berkilap & berkilap & berkilap \\
Opasitas & tidak tembus cahaya & tidak tembus cahaya & tidak tembus cahaya \\
Warna & kekuning-kuningan & kekuning-kuningan & kekuning-kuningan \\
Motilitas & tidak motil & tidak motil & tidak motil \\
Kebutuhan O2 & aerob & aerob & aerob \\
Tes oksidase & + & + & + \\
Tes peroksidase & + & + & + \\
\hline
\end{tabular}


2 hari masing-masing diproduksi pada media tumbuh cair dengan $\mathrm{pH} 7$ dalam aquades. Isolat B2-4 mempunyai aktivitas kitinase tertinggi pada $\mathrm{pH} 8$ fosfat substrat koloidal kitin $1 \%$ sebesar $17,54 \times 10^{-2} \mathrm{U} / \mathrm{ml}$. Berdasarkan karakteristik molekular urutan parsial 16S rDNA dengan primer 9F dan 1510R kedua isolat diidentifikasi sebagai anggota Stenotrophomonas sp.

\section{UCAPAN TERIMA KASIH}

Diucapkan terima kasih kepada Dra. Elidar Naiola atas bantuannya sehingga penelitian ini dapat terlaksana, serta kritik dan saran dalam penulisan makalah.

\section{DAFTAR PUSTAKA}

Dephut. 2007. Taman Nasional Bromo Tengger Semeru. Malang.www.dephut.go.id/INFORMAS I/ TN\%20INDOENGLISH/tn_bromo.htm (April 2007).

Don, J., Brenner, Krieg, N.R. \& Staley, J.T. 2003. The Proteobacteria, Part B The Gammaproteobacteria. Bergey's Manual of Systematic Bacteriology Second ed. Springer.

Faath, I. 1994. Isolation of Chitin Degrading Bacteria from Various Habitats. Microbial Diversity, Bonn.

Fersht, A. 1985. Enzyme Structure and Metabolism, 2nd ed. Freeman, San Fransisco.

Hsu, S.C. \& Lockwood, J.L. 1975. Powdered chitin agar as a selective medium for enumeration of actinomycetes in water and soil. Applied Microbiology 29: 422-426.

Kobayashi, S., Kiyosada, T. \& Shoda, S. 1997. A novel method for síntesis of chitobiose via enzymatic glycosylation using sugar oxazoline as glycosyl donor. Tetrahedron Lett 38: 2111-2112.

Lehninger, A.L. 1988. Dasar-dasar Biokimia. Jilid 1. Thenawijaya M. penerjemah Penerbit Erlangga, Jakarta. Terjemahan dari: Principles of Biochemistry.

Mahata, M.E., Dharma, A., Ryanto, I. \& Yose, R. 2008. Characterization of Extracellular Chitinase from Bacterial Isolate 99 and Enterobactersp. G-1 from Matsue City, Japan. Journal Mikrobiology Indonesia 2: 34-38.

Monreal, J. \& Reese, E.T. 1968. The Chitinase of Serea marcescens. Can. Journal Microbiol 15: 689-696.
Nasran, S., Farida, A. \& Ninoek, I. 2003. Produksi Kitinase dan Mitin Deasetilase dari Vibrio harveyi . Journal Penelitian Perikanan Indonesia 9(5): 33-38.

Patil, R.S., Ghormade, V. \& Despande, M.V. 2000. Chitinolytic Enzymes: an Exploration. Enzyme and Microbial Technology 26: 473-483.

Pelczar, M.J. \& Chan, E.C.S. 2005. Dasar-Dasar Mikrobiologi. Ratna Siri Hadioetomo et al. Penerjemah. Penerbit UI Press 87.

Priest, F.G. 1984. Extracellular Enzymes Van Nostrand Reinhold, England.

Radzicka, A. \& Wolfenden, R. 1995. "A proficient enzyme". id.wikipedia.org/wiki/Enzim-Tembolok. Science 6(267): 90931.

Rattanakit, N., Plikomol, A., Yano, S., Wakayama, M. \& Tachiki, T. 2002. Utilization of Shrim Shellfish Waste a Substrate for Solid-State Cultivation of a Culture Based on Chitinase Formation Which is necessary for Chitin Assimilation. Journal of Bioscience and Bioengineering 93(6): 550-556.

Rochima, E. 2006. Pemurnian dan Karakterisasi Kitin Deasetilase Termostabil dari Bacillus papandayan asal Kawah Kamojang Jawa Barat. Journal Bionatura 8(2): 193-209.

Soeka, Y.S. 2009. Kondisi Optimum Produksi Kitinase dari Aktinomisetes dengan Karakterisasi pH dan Suhu Enzim. Jurnal Berkala Penelitian Hayati. Edisi Khusus 3C: 57-61.

Terayama, H., Takahashi, S. \& Kuzuhara, H. 1993. Largescale preparation of $\mathrm{N}, \mathrm{N}$-diacetylchitobiose by enzymic degradation of chitin and its chemical modification. Journal Carbohydr. Chem 12: 81-93.

Volk, W.A. \& Wheeler, M.F.1988. Mikrobiologi Dasar. Jilid 1. Soenartono Adisoemarto Editor. Penerbit Erlangga Jakarta. Terjemahan dari: Basic Microbiology, fifth edition.

Webb, E.C. \& Dixon, M. 1979. Enzymes. Academia Press, New York.

Widhyastuti, N., Handayani R., Hastuti, A., Kasirah, Setianingrum, N., Manalu, J., Gita. \& Saskiawan, I. 2006. Studi Potensi Aktinomisetes untuk Produksi Enzim Kitinase Guna Menunjang Industri Farmasi. Laporan Teknik Pusat Penelitian Biologi-LIPI.

Widhyastuti, N. 2007. Produksi Kitinase Ekstraseluler Aspergillus rugulosus 501 secara Optimal pada Media Cair. Jurnal Berita Biologi 8(6): 547-553.

Yurnaliza. 2008. Senyawa Khitin dan Kajian Aktivitas Enzim Mikrobial Pendegradasinya. Digitized by USU digital library. (24 November 2008).

Yurnaliza, Margino, S. \& Sembiring, L. 2008. Kondisi Optimum untuk Produksi Kitinase dari Streptomyces Rkt5 dan Karakterisasi pH dan Suhu Enzim. Biota XIII 3: 169-174. 